\title{
Peningkatan Kinerja Guru dalam melaksanakan Pembelajaran yang Efektif melalui Supervisi Observasi Kelas di SDN Wora Tahun Pelajaran 2020-2021
}

\author{
Safruddin \\ SDN Wora \\ safruddin_sdnwora64@gmail.com
}

\begin{abstract}
Supervisi observasi kelas tidak bisa terlepas dari penilaian unjuk kerja guru dalam mengelola pembelajaran. Apabila di atas dikatakan, bahwa supervisi observasi kelas merupakan serangkaian kegiatan membantu guru mengembangkan kemampuannya mengelola proses pembelajaran, maka menilai unjuk kerja guru dalam mengelola proses pembelajaran merupakan salah satu kegiatan yang tidak bisa dihindarkan prosesnya. Penelitian ini bertujuan untuk mengetahui Peningkatan Kinerja Guru dalam melaksanakan Pembelajaran yang Efektif melalui Supervisi Observasi Kelas Di SDN Wora Tahun Pelajaran 2020-2021. Jenis ini adalah Penelitian Tindakan sekolah, Desain Penelitian Tindakan Sekolah yang digunakan sesuai dengan model Mc.Taggar. Setiap siklus meliputi perencanaan, tindakan, pengamatan, evaluasi serta refleksi. Subyek dalam penelitian ini adalah guru SDN Wora Tahun Pelajaran 2019/2020 sebanyak 12 orang guru. Instrumen yang digunakan dalam penelitian ini adalah lembar observasi dan Angket. Berdasarkan hasil penelitian yang telah dilakukan dapat ditarik kesimpulan bahwa: terdapat Peningkatan Kinerja Guru dalam melaksanakan Pembelajaran yang Efektif melalui Supervisi Observasi Kelas Di SDN Wora Tahun Pelajaran 2020-2021, dengan nilai prosentase peningktan kinerja guru sebesar 58,33\% pada siklus I dan $91,67 \%$ pada siklus II.
\end{abstract}

Keywords: Kinerja guru, Pembelajaran efektif, Supervisi observasi.

\section{PENDAHULUAN}

Tugas guru erat kaitannya dengan peningkatan sumber daya manusia melalui sektor pendidikan, oleh karena itu perlu upaya-upaya untuk meningkatkan mutu guru untuk

menjadi tenaga profesional. Agar peningkatan mutu pendidikan dapat berhasil. Sebagaimana dikemukakan oleh Tilaar dalam Dwikoranto (2017) peningkatan kualitas pendidikan tergantung banyak hal, terutama mutu gurunya. Untuk menjadikan guru sebagai tenaga professional maka perlu diadakan pembinaan secara terus menerus dan berkesinambungan, dan menjadikan guru sebagai tenaga kerja perlu diperhatikan, dihargai dan diakui keprofesionalannya.

Untuk membuat mereka menjadi profesional tidak semata-mata hanya meningkatkan kompetensinya baik melalui pemberian penataran, pelatihan maupun memperoleh kesempatan untuk belajar lagi namun perlu juga memperhatikan guru dari segi yang lain seperti peningkatan disiplin, pemberian motivasi, pemberian bimbingan melalui supervisi, pemberian insentif, gaji yang layak dengan keprofesionalnya sehingga memungkinkan guru menjadi puas dalam bekerja sebagai pendidik.

Secara konseptual, supervisi observasi kelas adalah serangkaian kegiatan membantu guru mengembangkan kemampuannya mengelola proses pembelajaran demi pencapaian tujuan pembelajaran. Supervisi observasi kelas merupakan upaya membantu guru-guru mengembangkan kemampuannya mencapai tujuan pembelajaran. Dengan demikian, berarti, esensi supervisi observasi kelas itu sama sekali bukan menilai kinerja guru dalam mengelola proses pembelajaran, melainkan membantu guru mengembangkan kemampuan profesionalismenya.

Namun kenyataan yang dijumpai adanya kepala sekolah dalam melaksanakan supervisi observasi kelas hanya datang ke sekolah dengan membawa instrument pengukuran kinerja. Kemudian masuk ke kelas melakukan pengukuran terhadap kinerja guru yang sedang mengajar. Setelah itu, selesailah tugasnya, seakan-akan supervisi observasi kelas sama dengan pengukuran 
kinerja guru dalam proses pembelajaran.

Supervisi observasi kelas sama sekali bukan penilaian unjuk kerja guru. Apalagi bila tujuan utama penilaiannya semata-mata hanya dalam arti sempit, yaitu mengkalkulasi kualitas keberadaan guru dalam memenuhi kepentingan akreditasi guru belaka. Hal ini sangat berbeda dengan konsep supervisi observasi kelas. Meskipun demikian, supervisi observasi kelas tidak bisa terlepas dari penilaian unjuk kerja guru dalam mengelola pembelajaran. Apabila di atas dikatakan, bahwa supervisi observasi kelas merupakan serangkaian kegiatan membantu guru mengembangkan kemampuannya mengelola proses pembelajaran, maka menilai unjuk kerja guru dalam mengelola proses pembelajaran merupakan salah satu kegiatan yang tidak bisa dihindarkan prosesnya. Penilaian kinerja guru dalam mengelola proses pembelajaran sebagai suatu proses pemberian estimasi mutu kerja guru dalam mengelola proses pembelajaran, merupakan bagian integral dari serangkaian kegiatan supervisi observasi kelas. Agar supervisi observasi kelas dapat membantu guru mengembangkan kinerjanya, maka untuk pelaksanaannya terlebih dahulu perlu diadakan penilaian kinerja guru, sehingga bisa ditetapkan aspek yang perlu dikembangkan dan cara meningkatkannya.

Berdasarkan Permasalah diatas peneliti melakukan penelitian dengan judul : "Peningkatan Kinerja Guru dalam melaksanakan Pembelajaran yang Efektif melalui Supervisi Observasi Kelas Di SDN Wora Tahun Pelajaran 2020-2021.

\section{METODE}

\section{Jenis Penelitian}

Penelitian ini adalah Penelitian Tindakan Sekolah. Penelitian ini dirancang dalam dua siklus. Setiap siklus meliputi perencanaan, tindakan, pengamatan, evaluasi serta refleksi (Azmin, 2019). Tahap kegiatan PTK mengacu pada Kemmis dan Mc.Taggar dalam Depdiknas (2007) sebagai berikut:

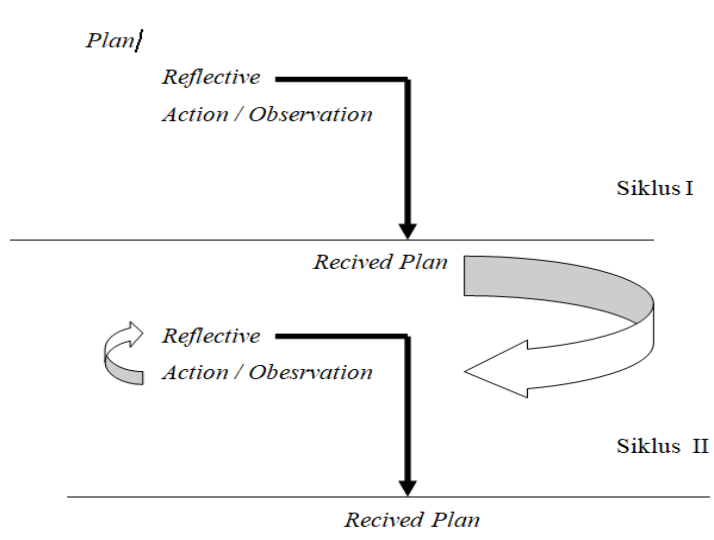

Gambar 1. Siklus Penelitian Tindakan Sekolah

\section{Waktu dan Tempat Penelitian}

PTS ini dilakukan pada SDN Wora tahun Pelajaran 2020-2021.

\section{Subyek Penelitian}

Subyek dalam penelitian ini adalah Guru SDN Wora Kecamatan yang berjumlah 12 orang pada tahun pelajaran 2020-2021.

\section{Rencana Tindakan}

Penelitian ini dilakukan selama 2 siklus. Masing-masing siklus terdiri dari tahapan perencanaan, pelaksanaan, observasi dan refleksi. Adapun tahapannya sebagai berikut:

1. Perencanaan, yaitu merencanakan tindakan yang akan dilakukan untuk memperbaiki, meningkatkan atau perubahan perilaku dan sikap sebagai solusi.

2. Pelaksanaan, yaitu tindakan yang akan dilakukan dalam upaya perbaikan, peningkatan atau perubahan yang diinginkan, mengamati atas hasil atau dampak dari tindakan yang dilaksanakan atau dikenakan terhadap siswa.

3. Tahap refleksi, yaitu tahapan mengkaji, melihat, dan mempertimbangkan atas hasil atau dampak dari tindakan dari berbagai keriteria.

4. Tahap revisi, yaitu melakukan refleksi dari hasil kegiatan yang direncanakan.

\section{Instrumen Penelitian}

Instrumen yang digunakan dalam penelitian ini adalah Lembar Observasi, dan lembar evaluasi Kinerja guru. 


\section{Teknik Analisis Data}

Teknik analisis data yang digunakan adalah secara deskriptif dengan menghitung besarnya peningkatan mutu guru melalui supervise. Indikator keberhasilan apabila terjadi peningkatan kinerja guru mencapai $85 \%$, dan individu guru telah mencapai ketuntasan dengan nilai rata rata 75 .

\section{HASIL DAN PEMBAHASAN Hasil Penelitian}

Penelitian ini berupa pembinaan kepala sekolah melalui supervisi observasi kelas di SDN Wora. Tujuan yang diharapkan adalah meningkatkan partisipasi guru dalam proses pembinaan ini, dalam upaya meningkatkan kinerja guru dalam melaksanakan pembelajaran yang efektif di SDN Wora. Penelitian tindakan sekolah dilaksanakan sesuai melalui tahapan sebagai berikut:

\section{Tahap Perencanaan}

Pada tahap ini peneliti mempersiapkan perangkat pembinaan yang terdiri dari rencana pembinaan, soal tes formatif 1 dan alat-alat pembinaan lain yang mendukung. Selain itu juga dipersiapkan lembar observasi peningkatan kinerja guru dengan melalui pembinaan supervisi observasi kelas kepala sekolah.

2. Tahap Pelaksanaan Tindakan

Tahapa Pelaksanaan tindakan pembinaan untuk siklus I dilaksanakan pada guru SDN Wora tahun pelajaran 2020-2021. Adapun proses pembinaan mengacu pada rencana pembinaan yang telah dipersiapkan.

Pengamatan dilaksanakan bersamaan dengan pelaksanaan pembelajaran. Pada akhir proses pembinaan guru diberi penilaian formatif I dengan tujuan untuk mengetahui tingkat pemahaman guru dalam meningkatkan kinerja guru sesuai dengan yang telah dilakukan. Adapun data hasil penelitian pada siklus I. adalah seperti pada gambar berikut :

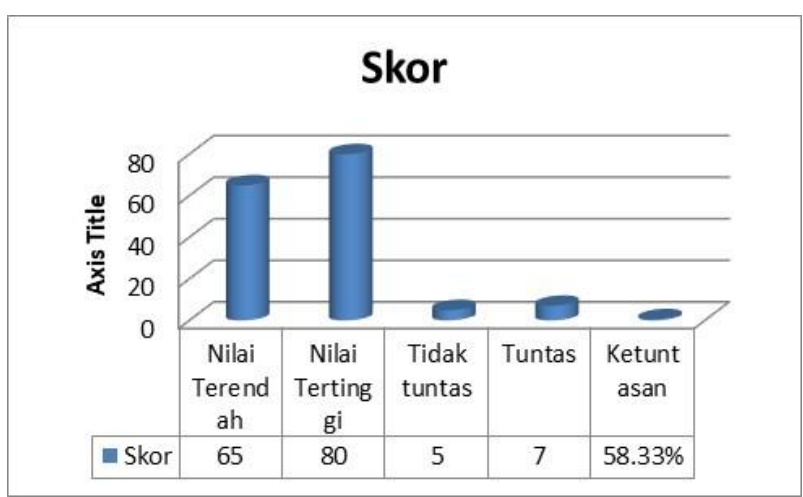

Gambar 1 Skor Supervisi Kepala Sekolah dalam meningkatkan kinerja guru Pada Siklus I

Dari gambar di atas dapat dijelaskan bahwa pembinaan yang dilakukan oleh kepala sekolah melalui supervisi observasi kelas diperoleh nilai ketuntasan kinerja guru sebesar 58,33\%. Baru 7 orang guru yang tuntas dari total 12 orang guru. Hasil tersebut menunjukkan bahwa pada siklus I kegiatan supervisi yang dilakukan oleh kepala sekolah masih berada dibawah standar ketuntasan yang ditetapkan yaitu sebesar $85 \%$.

3. Refleksi

Kegiatan supervisi yang telah dilakukan diperoleh informasi bahwa kepala sekolah masih kurang teliti dalam melakukan supervisi di sekolah, kurang memaksimalkan waktu, dan belum fokus melakukan supervisi karena ada tugas lain yang harus dikerjakan.

4. Revisi Rancangan

Pelaksanaan kegiatan supervisi pada siklus I ini masih adanya kekurangan, maka perlu adanya revisi pada siklus II, dengan meperbaiki hasil refleksi pada siklus I

\section{Hasil Siklus II}

\section{Tahap perencanaan}

Tahap perencanaan yang dilakukan adalah mempersiapkan instrument supervisi yang terdiri dari rencana pembinaan dan tindkan, instrument evaluasi dan alat-alat pembinaan yang mendukung.

2. Tahap kegiatan dan pelaksanaan

Proses supervisi mengacu pada rencana pembinaan yang telah dibuat, kemudian memperhatikan hasil refleksi pada siklus I, sehingga bias meminimalisisr kekurangan pada siklus II. Pengamatan dilaksanakan bersamaan dengan pelaksanaan proses belajar 
mengajar berlangsung. Pada akhir proses pembinaan guru diberi penilaian II dengan tujuan untuk mengetahui tingkat kinerja guru dalam melaksanakan tugasnya yang telah dilakukan. Hasil dari evaluasi yang dilakukan sebagai berikut :

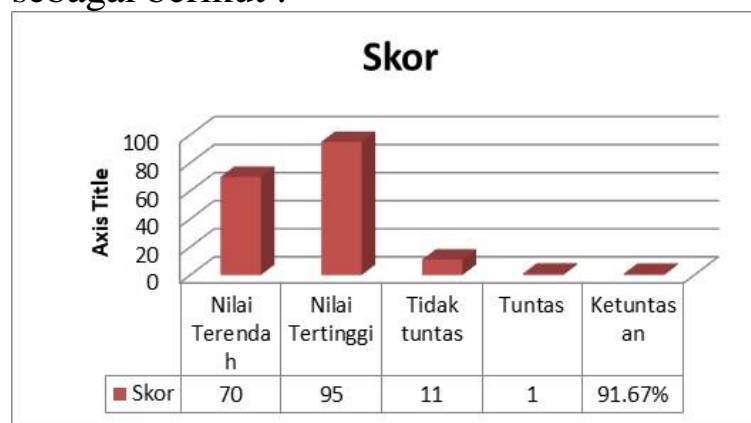

\section{Gambar 2. Skor Supervisi Kepala Sekolah dalam meningkatkan kinerja guru Pada Siklus II}

Berdasarkan gambar 2 di atas diperoleh nilai ketuntasan kinerja guru sebesar 91,67\% . Hasil ini didapatkan bahwa hanya 1 orang guru yang belum tuntas dari 12 orang guru. Hasil pada siklus II ini mengalami peningkatan lebih baik dari siklus I. Peningkatan pada siklus II ini dipengaruhi oleh adanya peningkatan kemampuan kepala sekolah dalam menerapkan pembinaan melalui supervisi observasi kelas sehingga guru menjadi lebih memahami tugasnya dan dapat meningkatkan kinerja guru dalam melaksanakan pembelajaran yang efektif.

\section{Refleksi}

Pada tahap refleksi dalam proses pembinaan melalui supervisi kunjunghan kelas. Dari data-data yang telah diperoleh dapat duraikan sebagai berikut: Selama proses pembinaan kepala sekolah telah melaksanakan semua pembinaan dengan baik. Meskipun ada beberapa aspek yang belum sempurna, tetapi persentase pelaksanaannya untuk masing-masing aspek cukup besar, Berdasarkan data hasil pengamatan diketahui bahwa guru aktif selama proses pembinaan berlangsung. Hasil pembinaan guru oleh kepala sekolah melalui supervisi kunjunghan kelas pada siklus II mencapai ketuntasan dari yang ditetapkan adalah $85 \%$.

4. Revisi Pelaksanaaan

Pelaksanaan supervisi sudah berjalan dengan baik. Maka selanjutnya memaksimalkan dan mempertahankan apa yang telah ada dengan tujuan agar pada pelaksanaan pembinaan selanjutnya baik melalui supervisi akademis maupun supervisi kunjunghan kelas.

\section{B. Pembahasan}

Berdasarkan hasil penelitian yang dilakukan bahwa terdapat Peningkatan Kinerja Guru dalam melaksanakan Pembelajaran yang Efektif melalui Supervisi Observasi Kelas Di SDN Wora Tahun Pelajaran 2020-2021, dengan nilai prosentase peningktan kinerja guru sebesar $58,33 \%$ pada siklus I dan 91,67 \% pada siklus II.

Peningkatan ini disebabkab oleh proses pembinaan kepala sekolah telah melaksanakan semua pembinaan dengan baik. Meskipun ada beberapa aspek yang belum sempurna, tetapi persentase pelaksanaannya untuk masing-masing aspek cukup besar, Berdasarkan data hasil pengamatan diketahui bahwa guru aktif selama proses pembinaan berlangsung. Hasil pembinaan guru oleh kepala sekolah melalui supervisi kunjunghan kelas pada siklus II mencapai ketuntasan dari yang ditetapkan adalah

\section{KESIMPULAN}

Berdasarkan hasil penelitian yang telah dilakukan dapat ditarik kesimpulan bahwa: terdapat Peningkatan Kinerja Guru dalam melaksanakan Pembelajaran yang Efektif melalui Supervisi Observasi Kelas Di SDN Wora Tahun Pelajaran 2020-2021, dengan nilai prosentase peningktan kinerja guru sebesar $58,33 \%$ pada siklus I dan 91,67 $\%$ pada siklus II.

\section{DAFTAR PUSTAKA}

Arikunto. S. 2010. Prosedur Penilitian Suatu Pendekatan Praktek. Jakarta:Renika Cipta.

Azmin, N., \& Nasir, M. (2019). $\begin{array}{llr}\text { PENERAPAN } & \text { MODEL } \\ \text { PEMBELAJARAN 5E } & \text { UNTUK } \\ \text { MENINGKATKAN } & \\ \text { KETERAMPILAN PROSES } & \text { SAINS } \\ \text { DAN SIKAP ILMIAH } & \text { SISWA } \\ \text { KELAS VIII SMP NEGRI } 6 & \text { KOTA }\end{array}$ 
BIMA. ORYZA Jurnal Pendidikan Biologi, 8(2), 40-46.

Depdiknas RI 2007, Peraturan No 12 Tentang Kompetensi Pengawas.Jakarta : Depdiknas.

Dwikoranto, 2017. Peningkatan Kinerja Guru Dalam Proses Pembelajaran Melalui Supervisi Akademik Di SMK Muhammadiyah 2 Yogyakarta. Jurnal Tajdidiukasi, Volume VII, No. 2 Juli 2017

Glickman, C.D., Gordon, S.P., and RossGordon, J.M. (2007). Supervisionand. Instructional Leadership A Development Approach. Seventh Edition. Boston 